\title{
MOUNTAIN PINE BEETLE INFESTATION: \\ CYCLING AND SUCCESSION IN LODGEPOLE PINE FORESTS
}

\author{
W. H. Romme \\ Department of Biology \\ Fort Lewis Callege \\ Durango, $\mathrm{CO}$
}

J. B. Yavitt and D. H. Knight

Department of Botany

University of Wyoming

Laramie

J. Fedders

Department of Biology

West Virginia University

Morgantown

\section{Objectives}

This work began in 1980 with the objective of studying the effects of mountain pine beetle outbreaks in Yellowstone and Grand Teton National Parks and the surrounding area. The immediate effects of outbreaks on stand structure have been documented, but little is known about long-term influences on ecosystem processes such as primary productivity, material cycling, and succession. Thus, our research deals with the effects of beetle outbreaks on (1) rates of growth in surviving trees and total stand productivity, (2) dead woody fuels and fire risk, (3) forest succession, and (4) nutrient cycling.

\section{Methods, Results, and Conclusions}

These subjects have been summarized in the Annual Report for 1985. We presently are completing the writing of a second technical paper and the final report on this project. The first paper (Romme, Knight and Yavitt, 1986) dealt with the effects of beetle outbreaks on primary productivity. The second paper will focus on the effects of outbreaks on dead woody fuels and fire risk; a preliminary version of this paper was presented at the annual meeting of the Ecological Society of America in 1986 (Romme, Knight and Fedders, 1986). When the second paper has been accepted for publication by an ecological journal, we will assemble the two papers, plus supporting maps and additional unpublished data, into our final report to the UW-NPS Research Center. 


\section{Iiterature Cited}

Romme, W. H., D. H. Knight and J. B. Yavitt. 1986. Mountain pine beetle outbreaks in the Rocky Mountains: regulators of primary productivity? A mer. Naturalist 127(4):484-494.

Romme, W. H., D. H. Knight and J. Fedders. 1986. Mountain pine beetle outbreaks in the Rocky Mountains: effects on fuels and fire in lodgepole pine forest. Prog. of the IV Intl. Cong. of Ecol, 7lst Ann. Meet. of the Ecol Soc. of A mer., and 5th Meeting of the Intl. Soc. of Ecol. Modelling, p. 290 (abstract) 